\title{
Alterations in expression of endometrial genes coding for proteins secreted into the uterine lumen during conceptus elongation in cattle
}

Niamh Forde ${ }^{1,5^{*}}$, Jai P Mehta ${ }^{2}$, Paul A McGettigan', Solomon Mamo ${ }^{1}$, Fuller W Bazer ${ }^{3}$, Thomas E Spencer ${ }^{4}$ and Pat Lonergan ${ }^{1}$

\begin{abstract}
Background: We hypothesized that genes that are up-regulated in the uterine endometrium at the initiation of conceptus elongation in cattle, and that encode for secreted proteins, contribute to the composition of the uterine luminal fluid (ULF) and ultimately, drive conceptus elongation. The aims of this study were to: 1) screen endometrial transcriptomic data for genes that encode secreted proteins on Day 13;2) determine temporal changes in the expression of these genes during the estrous cycle/early pregnancy; 3) determine if expression of these genes is affected by altered concentrations of progesterone (P4) in vivo and 4) determine if the protein products of these genes are detectable in ULF.

Results: Of the fourteen candidate genes examined, quantitative real-time PCR analysis revealed the expression of APOA1, ARSA, DCN, LCAT, MUC13, NCDN, NMN, NPNT, NXPH3, PENK, PLIN2 and TINAGL1 was modulated in the endometrium $(\mathrm{P}<0.05)$ as the estrous cycle/early pregnancy progressed. APOA1, DCN and NPNT expression was higher in cyclic compared to pregnant heifers, and pregnancy increased $(P<0.05)$ the expression of LCAT, NCDN, NMN, PLIN2 and TINAGL1. The magnitude of the increase in expression of APOA1, PENK and TINAGL1 on Day 13 was reduced $(P<0.05)$ in heifers with low $P 4$. Furthermore, low $P 4$ decreased $(P<0.05)$ the expression of LCAT and NPNT on Day 7, while an early increase $(P<0.05)$ in the expression of NXPH3 and PLIN2 was observed in heifers with high P4. The protein products of 5 of the candidate genes (APOA1, ARSA, LCAT, NCDN and PLIN) were detected in the ULF on either Days 13, 16 or 19 of pregnancy.
\end{abstract}

Conclusion: Using a candidate gene approach, we determined that both P4 concentration and the presence of the conceptus alter endometrial expression of PLIN2, TINAGL1, NPNT, LCAT, NMN and APOA1. Comparison of the expression profiles of these genes to proteins detected in ULF during conceptus elongation (i.e., Days 13 through 19) revealed the presence of APOA1, ARSA, LCAT, NCDN as well as members of the PLIN family of proteins that may play roles in driving conceptus elongation in cattle.

Keywords: Uterus, Endometrium, Gene expression, Histotroph, Embryo, Progesterone, Estrous cycle, Pregnancy, Proteomics

\footnotetext{
* Correspondence: niamh.forde@ucd.ie

${ }^{1}$ School of Agriculture and Food Science, University College Dublin, Dublin,

Ireland

${ }^{5}$ Veterinary Sciences Centre, School of Agriculture and Food Science,

University College Dublin, Belfield, Dublin 4, Ireland

Full list of author information is available at the end of the article
} 


\section{Background}

In cattle, the majority of pregnancy loss is attributed to early embryonic loss prior to maternal recognition of pregnancy [1,2], which occurs by approximately Day 16 following conception $[3,4]$. During this period, following successful fertilization, the developing embryo enters the uterus on Days 4 to 5 and forms a blastocyst by Day 7 . Following hatching of the blastocyst from the zona pellucida (Day 9 to 10), the conceptus (embryo and associated extra-embryonic membranes) becomes ovoid in shape. Conceptus elongation is initiated by Days 13 to 14 , and is characterized by a period of rapid growth of the trophectoderm cells that is completed by Days 19 to 20. Elongation of the conceptus requires molecules that are transported or secreted by the luminal (LE) and glandular (GE) epithelial cells of the uterine endometrium [5]. These secretions make up the uterine lumen fluid (ULF or histotroph), and include proteins, amino acids, lipids, glucose and ions, which are required for successful elongation, as evidenced by the failure of blastocysts to elongate in vivo in the uterine gland knock out ewe [6,7] and the inability to replicate elongation in vitro in cattle $[8,9]$.

One of the pre-requisites for establishing a uterine environment capable of supporting conceptus elongation is an adequate post-ovulatory rise in circulating progesterone (P4) concentrations. In both cattle and sheep, elevated $\mathrm{P} 4$ in the post-ovulatory period results in advanced conceptus elongation [10-12]. As a consequence, the elongating conceptus produces more interferon-tau (IFNT) which is detectable in the uterine lumen [13,14] and which is associated with increased pregnancy rates [15-17]. The effects of P4 do not directly affect the developing embryo [18] but act indirectly by altering the transcriptome of the endometrium and subsequently the composition of the ULF [19-21].

One of the strategies employed to identify molecules that regulate conceptus elongation in ruminants has been to characterize the temporal changes in endometrial gene expression during the period when conceptus elongation occurs, and to infer from the localization of transcripts whether the proteins for which they encode contribute to the composition of the ULF. In sheep, genes localized to the uterine LE and superficial glandular epithelium (sGE) have been associated with 3 main classes of molecules: (i) proteins that are detectable in the uterine luminal fluid (ULF; GlyCAM-1 [22], CTSL [23], STC1 [24], CST3 [25], GRP [26], and IGFBP1 [27]), (ii) enzymes that produce constituents of the ULF (PTGS2 and HSD11B1, involved in prostaglandin [28] and cortisol [29] production, respectively) and (iii) active transporters of ULF molecules (SLC2A1, SLC5A1, SLC1A5, SLC7A2 involved in amino acid [30,31], glucose [32] and ion transport). To date, detailed data on ULF composition in cattle are scarce, although some studies have detected the protein products of a small number of genes encoding for secreted proteins in the ULF including IGFBP1 [27], retinol binding protein [33,34], legumain and TIMP2 [35]. Caution in extrapolating the abundant data on ULF composition confirmed in sheep [36] to the bovine model is required. For example, despite the similarities in the transcriptomic changes that occur during the estrous cycle and early pregnancy, discrepancies in expression exist, as exemplified by LGALS15, which has a functional role in early pregnancy in sheep [37], but is not expressed in the bovine endometrium although is present in the bovine genome [38].

We have recently generated a considerable amount of data on the transcriptomic signature of the bovine endometrium before and during the initiation of conceptus elongation [39-42]. We hypothesize that genes that are up-regulated at the initiation of conceptus elongation, and that encode for secreted proteins, may contribute to the composition of the ULF and ultimately, drive conceptus elongation. With this in mind, the aims of this study were to: 1) screen endometrial transcriptomic data (generated by microarray and RNA sequencing) for genes that encode secreted proteins on Day 13 following estrus; 2) determine temporal changes in the expression of these genes during the estrous cycle/early pregnancy; 3) determine if expression of these genes is affected by altered concentrations of $\mathrm{P} 4$ in vivo that are known to impact conceptus elongation; and 4) determine if the protein products of these genes are detectable in ULF.

\section{Methods}

All experimental procedures involving animals were licensed by the Department of Health and Children, Ireland, in accordance with the Cruelty to Animals Act (Ireland 1876) and the European Community Directive 86/609/EC and were sanctioned by the Animal Research Ethics Committee of University College Dublin. Unless otherwise stated, all chemicals and reagents were sourced from Sigma (Dublin, Ireland).

\section{Selection of candidate genes from transcriptomic data sets}

To identify candidate genes from our gene expression data sets, two separate approaches were taken (Table 1). RNA sequencing (RNA-SEQ) data from cyclic heifers on Day 13 of the estrous cycle were screened to identify the most highly expressed transcripts in the endometrium that were not detectable in the conceptus at the corresponding stage of development [41,43] using a previously described approach [44]. Briefly, only transcripts detected in four out of five replicates for either the endometrium or conceptus, with an RPKM (reads per kilobase of exon per million mapped sequence reads) value of at least 0.5 were considered. The resulting list 
Table 1 Candidate genes selected for analysis on the basis of their increased expression on Day 13 as compared to Day 7 of the estrous cycle from reference [42] and RNA sequencing (RNA-SEQ) data of pregnant and cyclic endometria on Day 13 from reference [41] for the most abundant genes expressed in the endometria, but not detected in the conceptus

\begin{tabular}{|c|c|c|c|c|c|c|}
\hline Gene name & Gene description & $\begin{array}{l}\text { Gene ID/Affymetrix } \\
\text { probe ID }\end{array}$ & Platform & $\begin{array}{l}\text { Fold change } \\
\text { (log2) on } \\
\text { Day } 13 \text { v Day } 7\end{array}$ & $\begin{array}{l}\text { Average TPM } \\
\text { (Day 13) }\end{array}$ & Reference \\
\hline DCN & Decorin Precursor (Bone proteoglycan II)(PG-S2) & ENSBTAT00000004562 & RNA-SEQ & N/A & 1464.006 & [44] \\
\hline MGP & Bos taurus matrix Gla protein (MGP), mRNA. & ENSBTAT00000016414 & RNA-SEQ & N/A & 2371.502 & [44] \\
\hline PENK & $\begin{array}{l}\text { Proenkephalin A Precursor [Contains Synenkephalin; } \\
\text { Met-enkephalin(Opioid growth factor)(OGF); } \\
\text { Met-enkephalin-Arg-Gly-Leu;Leu-enkephalin; } \\
\text { Enkelytin;Met-enkephalin-Arg-Phe] }\end{array}$ & ENSBTAT00000006478 & RNA-SEQ & N/A & 907.056 & [44] \\
\hline PLIN2 & $\begin{array}{l}\text { Adipophilin (Adipose differentiation-related } \\
\text { protein)(ADRP) }\end{array}$ & ENSBTAT000000047728 & RNA-SEQ & N/A & 62.58 & [44] \\
\hline APOA 1 & Apolipoprotein A-I & Bt.1229.1 & Array & 2.64 & N/A & [45] \\
\hline ARSA & Arylsulfatase A & Bt.1076.1 & Array & 3.14 & N/A & [45] \\
\hline CYR61 & Cysteine-rich, angiogenic inducer, 61 & Bt.22000.1 & Array & 2.87 & N/A & [45] \\
\hline LCAT & Lecithin-cholesterol acyltransferase & Bt.11126.3 & Array & 2.91 & N/A & [45] \\
\hline MUC13 & Mucin 13 , cell surface associated & Bt.12140.1 & Array & 26.72 & N/A & [45] \\
\hline NMN & Neuromedin N & Bt.10630.1 & Array & 2.72 & N/A & [45] \\
\hline NCDN & Neurochondrin & Bt.8806.1 & Array & 3.28 & N/A & [45] \\
\hline NPNT & Nephronectin & Bt.7393.1 & Array & 9.96 & N/A & [45] \\
\hline NXPH3 & Neurexophilin 3 & Bt.27342.1 & Array & 6.96 & N/A & [45] \\
\hline TINAGL1 & Tubulointerstitial nephritis antigen-like 1 & Bt. 1300.1 & Array & 12.84 & N/A & [45] \\
\hline
\end{tabular}

All genes selected for analysis encoded for secreted or extracellular proteins as determined by DAVID analysis (http://david.abcc.ncifcrf.gov/).

was screened to identify genes expressed only in cells of the endometrium (i.e., not in the conceptus) on Day 13. This list was then subjected to DAVID analysis (http:// david.abcc.ncifcrf.gov/) to identify those genes that encoded for proteins assigned to the gene ontology terms 'secreted' or 'extracellular'. Additional candidate genes were selected on the basis of a significant increase in expression on Day 13 compared to Day 7 of the estrous cycle $[40,42]$.

Experiment 1: temporal changes in endometrial expression of candidate genes from cyclic and pregnant heifers during the pre-implantation period of early pregnancy

The estrous cycles of cross-bred beef heifers $(n=100$, predominantly Charolais and Limousin cross) were synchronized by insertion of an intravaginal controlled internal drug release (CIDR) device (1.94 g P4; InterAg, Hamilton, New Zealand) for 8 days. One day prior to CIDR removal each heifer received an intramuscular injection of a prostaglandin $\mathrm{F}_{2 \alpha}(\mathrm{PG})$ analogue (Estrumate, Shering-Plough Animal Health, Hertfordshire, UK; $2 \mathrm{ml}$ equivalent to $0.5 \mathrm{mg}$ cloprostenol). Only those heifers observed in standing estrus (Day 0) were utilized further and were assigned randomly to either an inseminated group (Pregnant, P: $\mathrm{n}=59$ ) or an un-inseminated cyclic control group (C: $n=24)$. Heifers were slaughtered on either Day 7, 10, 13 or 16 (C group) of the estrous cycle or Day $7,10,13,16$ or 19 (P group) following estrus and insemination. These stages correspond in pregnant heifers to blastocyst formation, blastocyst hatching, initiation of conceptus elongation, maternal recognition of pregnancy and initiation of implantation, respectively. Thirty minutes after slaughter the uterine horn ipsilateral to the corpus luteum (CL) was flushed with $20 \mathrm{ml}$ of $10 \mathrm{mM}$ Tris ( $\mathrm{pH}$ 7.2). ULF was centrifuged at 3,000 g for $10 \mathrm{~min}$, supernatant removed and snap frozen in liquid nitrogen prior to proteomic analysis. In the inseminated group, only those reproductive tracts from which an embryo/conceptus at the expected stage of development was recovered (Day 7: blastocyst; Day 10: hatched blastocyst; Day 13: ovoid ; Days 16 and 19: filamentous conceptus) were processed further. Intercaruncular endometrial tissue was dissected free from the underlying myometrium and snap-frozen in liquid nitrogen for RNA extraction and quantitative real-time PCR (qPCR) analysis.

\section{Experiment 2: P4 effects on endometrial gene expression} of candidate genes

In order to investigate the effect of circulating $\mathrm{P} 4$ on the expression of these candidate genes, we examined the 
endometrium of heifers with low, normal and high P4 from previously generated tissue samples. The estrous cycles of cross-bred beef heifers were synchronized as described in Experiment 1 and those observed in standing estrus $(n=52)$ were randomly assigned to one of three treatments: (i) cyclic heifers normal P4, no treatment $(\mathrm{n}=5)$; (ii) cyclic heifers, high $\mathrm{P} 4(\mathrm{n}=5)$, receiving an intravaginal P4 device on Day 3 of the estrous cycle to increase concentrations of P4 in blood [11]; and (iii) cyclic heifers, low $\mathrm{P} 4(\mathrm{n}=5)$ receiving 3 intramuscular injections of a PG analogue (Estrumate) on Days 3, 3.5 and 4 of the estrous cycle to reduce P4 output from the CL [40]. The progesterone profiles of animals on these treatments have been extensively reported by us in previous papers [11,18,39,40,42,45]. Following slaughter, intercaruncular endometrial tissue from the tip of the uterine horn ipsilateral to the CL was recovered, snap frozen in liquid nitrogen for subsequent RNA extraction and analyzed using qPCR for selected genes.

\section{Quantitative real-time PCR analysis (qPCR)}

All qPCR analyses were performed as previously described [42]. Total RNA was extracted from $100 \mathrm{mg}$ of intercaruncular endometrial tissue using Trizol reagent as per manufacturer's instructions. Both RNA clean-up and on-column DNase treatment were performed (Qiagen, Crawley, Sussex, UK) and the subsequent RNA was analyzed for both quality and quantity using the Agilent Bioanalyzer (Agilent Technologies, Santa Clara, CA, USA) and Nanodrop 1000 (Thermo Fischer Scientific, DE, USA), respectively. One microgram of total RNA was converted to complementary DNA (cDNA) using Superscript III (Applied Biosystems, Foster City, CA, USA) and random hexamers as per manufacturer's instructions. All primers were designed using PrimerBLAST software (www.ncbi.nlm.nih.gov/tools/primerblast/) to span exon-exon boundaries where possible. Each qPCR reaction was carried out in duplicate with 50 ng of cDNA, optimized primer concentrations (Table 2) and $7.5 \mu \mathrm{l}$ FAST Sybrgreen mastermix (Applied Biosystems, Foster City, CA, USA) in a final reaction volume of $15 \mu \mathrm{l}$. All reactions were carried out using the 7500 Fast RealTime PCR System (Applied Biosystems, Foster City, CA, USA) with the following cycling conditions: $2 \mathrm{~min}$ at $50^{\circ} \mathrm{C}$; $10 \mathrm{~min}$ at $95^{\circ} \mathrm{C}$; and 40 cycles of $95^{\circ} \mathrm{C}$ for $15 \mathrm{sec}$ and $60^{\circ} \mathrm{C}$ for $1 \mathrm{~min}$. A dissociation curve was included in each run to ensure specificity of amplification, while a standard curve was included for each gene of interest as well as for the normalizer genes (ACTB and RPL19) to determine primer efficiencies. All raw cycle threshold values were then imported into qbase ${ }^{\text {plus }}$ software (Biogazelle, Zwijnaarde, Belgium) used to calibrate and normalize data, as well as calculate expression values for each gene in arbitrary units (CNRQ).

Table 2 Primer information used for quantitative real time PCR analysis of candidate genes

\begin{tabular}{|c|c|c|c|c|c|}
\hline $\begin{array}{l}\text { Entrez gene } \\
\text { symbol }\end{array}$ & gene name & $\begin{array}{l}\text { Accession } \\
\text { number }\end{array}$ & Forward primer sequence & Reverse primer sequence & $\begin{array}{l}\text { Product } \\
\text { length (bp) }\end{array}$ \\
\hline ACTB & Actin, beta & NM_173979.3 & CGCCATGGATGATGATATTGC & AAGCCGGCCTTGCACAT & 66 \\
\hline$A P O A 1$ & Apolipoprotein A-I & NM_174242.3 & GCTGGCCATTGAGGTCACCCAC & GCTGCCAGAAATGCCGAGCCT & 103 \\
\hline ARSA & Arylsulfatase A & NM_001075205.1 & GCCTTTGCCCGCGACCTCAT & TGGGTGTGGTGGGAGGCGTA & 80 \\
\hline CYR61 & $\begin{array}{l}\text { Cysteine-rich, angiogenic } \\
\text { inducer, } 61\end{array}$ & NM_001034340.2 & TGCAGAGCTCAGTCGGAGGGC & GGCGCCGTCGATACATGTGC & 111 \\
\hline$D C N$ & Decorin & NM_173906.4 & ACTCTTCAGGAGCTGCGTGTCCA & GCGGGTTGGTGCCAAGTTCTACG & 106 \\
\hline LCAT & $\begin{array}{l}\text { Lecithin-cholesterol } \\
\text { acyltransferase }\end{array}$ & NM_001046069.2 & CGGCCCGTCATCCTCGTGCC & AAGTCCTCCGTCTTGCGGTAGCA & 104 \\
\hline MGP & Matrix Gla protein & NM_174707.2 & GCAAAAGCCCAAGAGAGAATCCGA & ACACCATGGCATAGCGTTCGCA & 103 \\
\hline MUC13 & $\begin{array}{l}\text { Mucin 13, cell surface } \\
\text { associated }\end{array}$ & XM_002702427.2 & ACGGGCTGGTGAGACCAAAACC & GCAGTCAGCTGTCCCGTTGC & 116 \\
\hline NCDN & Neurochondrin & NM_001045931.1 & TCTCCAGCTCTGCAGGGGACG & GGCCACGTGGGATTGCGACA & 81 \\
\hline NMN & Neuromedin N & NM_173945.4 & GAGCCCCCTTCAGCCTGTTCC & GCCAGAAGAATCATGCACACCAGC & 104 \\
\hline NPNT & Nephronectin & XM_591031.5 & TCTCAGCAGCCAAAGGCCCG & CTGACAGGCACAGGTCCCCT & 90 \\
\hline $\mathrm{NXPH3}$ & Neurexophilin 3 & NM_001192824.1 & ATGACGGTCCGCCAGGCTCA & CCGCTTTCGAGGCATCCGGG & 80 \\
\hline PENK & Proenkephalin & NM_174141.2 & GACGCCGAGGACCGCGAGAG & CCATGGGGTTGCCGCTGTTCGG & 120 \\
\hline PLIN2 & Periliphin 2 & NM_173980.2 & TCTTCGCGCTTGGGCGTCTG & CCACCCTGGTCACCACACTCAGTT & 101 \\
\hline RPL19 & Ribosomal protein L19 & NM_001040516.1 & GAAAGGCAGGCATATGGGTA & TCATCCTCCTCATCCAGGTT & 86 \\
\hline TINAGL1 & $\begin{array}{l}\text { Tubulointerstitial nephritis } \\
\text { antigen-like } 1\end{array}$ & XM_003585097.1 & CTCGGGAGGCCGGAGCGATA & GTCAGGCAGCGTCTCCTCGC & 81 \\
\hline
\end{tabular}




\section{Proteomic analysis of uterine luminal fluid during the peri-implantation period of pregnancy}

Nano LC MS/MS analysis was carried out on ULF from pregnant heifers on Days 13 and 16 to identify proteins involved in conceptus elongation (Applied Biomics, Inc, Hayward, CA, USA). Samples (pool of $n=5$ heifers on Day 13 and Day 16) were exchanged into $50 \mathrm{mM}$ ammonium bicarbonate buffer, DTT added to a final concentration of $10 \mathrm{mM}$, and samples were incubated at $60^{\circ} \mathrm{C}$ for $30 \mathrm{~min}$ followed by cooling to room temperature (RT). Iodoacetamide was added to a final concentration of $10 \mathrm{mM}$ and incubated in the dark for $30 \mathrm{~min}$ at RT. A tryptic digestion was performed at $37^{\circ} \mathrm{C}$ overnight. Nano LC was carried out using a Dionex Ultimate 3000 (Milford, MA, USA). Tryptic peptides were loaded into an $\alpha$-Precolumn Cartridge and separated using an acetonitrile gradient (ranging from 5\% to $60 \%$ ) on the Nano LC column. Fractions were collected at $20 \mathrm{sec}$ intervals followed by Mass Spectrometry analysis on AB SCIEX TOF/TOF ${ }^{\text {rm }} 5800$ System (AB SCIEX, Framingham, MA, USA). Mass spectra were acquired in reflectron positive ion mode. TOF/TOF tandem MS fragmentation spectra were acquired for each ion, averaging 4000 laser shots per fragmentation spectrum (excluding trypsin autolytic peptides and other known background ions). Identification of the resulting peptide mass and the associated fragmentation spectra were submitted to GPS Explorer workstation equipped with MASCOT search engine (Matrix Science, London, UK) to search the nonredundant database of National Center for Biotechnology Information (NCBInr). Searches were performed without constraining protein molecular weight or isoelectric point, with variable carbamidomethylation of cysteine and oxidation of methionine residues, and with one missed cleavage also being allowed in the search parameters.

ITRAQ analysis was carried out on ULF recovered from pregnant heifers on Days 13, 16 and 19 ( $n=4$ per day) to identify quantitative changes in the protein content (Proteome factory, Berlin, Germany). Two $\mathrm{ml}$ of each individual sample was precipitated in $10 \mathrm{ml}$ of $100 \% \mathrm{EtOH}$ overnight, the resulting pellet was washed twice and resuspended in $40 \mu \mathrm{l}$ of lysis buffer and centrifuged at 13,000 g. The supernatant was incubated for $30 \mathrm{~min}$ at RT with $10 \mathrm{mM}$ iodoacetamide in the dark and the resulting protein concentration was determined by Bradford assay. One hundred micorgrammes of total protein was subjected to trypsin digestion (Promega, Mannhein, Germany) at $37^{\circ} \mathrm{C}$ overnight with additional trypsin added and the reaction continued for a further $3 \mathrm{~h}$. The resulting peptides were acidified with formic acid ( $\mathrm{pH} 2.0)$, desalted with Macro spin tips containing Vydac C18 material (Nest group, Southborough, MA, USA) and lyophilized. The lyophilized samples were dissolved in $45 \mu \mathrm{l}$ of iTraq buffer (AB SCIEX, Framingham, MA, USA) and $30 \mu \mathrm{l}$ of each sample were reacted with appropriate iTraq reagent for $2 \mathrm{~h}$ at RT as per the manufacturer's protocol. The reaction was stopped with $50 \mu \mathrm{l}$ of $20 \%$ formic acid, $\mathrm{pH} 2.0$ and dried by lyophilisation. Strong cation exchange (SCX) was performed on a PolySULFOETHYL A column $(200 \mathrm{~mm} \times 2.1 \mathrm{~mm}, 5 \mu \mathrm{m}$, $200 \AA$, PolyLC, Columbia, MD, USA) using an Agilent 1100 HPLC system (Agilent, Karlsruhe, Germany) with 18 fractions collected per sample. Protein identification and quantification of iTRAQ reporter ions was performed using nanoLC-ESIMS/MS which consisted of an Agilent 1100 nanoLC system (Agilent, Karlsruhe, Germany), PicoTip emitter (New Objective, Langhorne, PA, USA) and a QExactive quadrupole-Orbitrap mass spectrometer (ThermoFisher Scientific, Bremen, Germany). The dried SCX peptide fractions were resuspended in $80 \mu \mathrm{l}$ of MilliQ water containing $0.1 \%$ formic acid and $1 \%$ acetonitrile. After trapping $40 \mu \mathrm{l}$ of each sample the peptides were desalted for 5 min on an enrichment column (Zorbax SB C18, $0.3 \mathrm{~mm} \times 5 \mathrm{~mm}$, Agilent, Karlsruhe, Germany) using a solution of $1 \%$ acetonitrile and $0.1 \%$ formic acid solution. All peptides were separated on a Zorbax 300 SB C18, $75 \mu \mathrm{m} \times 150 \mathrm{~mm}$ column (Agilent, Karlsruhe, Germany) for $110 \mathrm{~min}$, using an acetonitrile gradient containing 5-25\% acetonitrile in $0.1 \%$ formic acid. The mass spectrometer was operated in a data-dependent mode by subjecting the ten most abundant ions of each survey spectrum (nominal resolution 35.000) to HCD fragmentation (normalized collision energy at $40 \%$, Resolution 17.500). MSMS peak lists were extracted to mascot generic format files and searched by the Mascot search algorithm against the bovine IPI database that has been curated from duplicate entries. The mass tolerance was set to $5 \mathrm{ppm}$ for peptide masses and $0.02 \mathrm{Da}$ for fragment ions. Quantitative information was obtained with the Protein ratio type set to "weighted" and normalization to "summed intensities".

\section{Data analysis}

All data were analysed using the statistical package SAS (SAS Institute Inc., Cary, NC). For gene expression analysis, the log of the CNRQ values in arbitrary units was used and analysis was performed using the general linear model procedure (PROC GLM) with day, pregnancy status and/or P4 status, when appropriate, as the main effects. Treatment effects on gene expression were separated by Tukey's test and a $\mathrm{p}$ value of $\leq 0.05$ was considered significant.

\section{Results}

Identification of candidate genes from large-scale transcriptomic data sets

From the RNA-SEQ data, a total of 208 distinct transcripts with an extracellular localization were uniquely 
detected in the endometrium (Additional file 1: Table S1). Three genes had RPKM values of greater than 1,000 in the endometrium (matrix gamma-carboxyglutamic acid, $M G P$ 1732 \pm 144 RPKM; proenkephalin, PENK 1278 \pm 336 RPKM; and decorin, $D C N 1048 \pm 136$ RPKM) and were chosen for further analysis. Fourteen genes had expression values in the endometrium of between 100 and 1,000 RPKM (AGT, APOD, AZGP1, CLEC3B, COL1A2, COL3A1, IP1, ISG15, LUM, PDZK1, PIP, PLAT, PRSS16, SAA1 and SPARCL1). Of the remaining genes, 71 had expression levels between 10 and 100 RPKM, while 120 genes had expression of $<10$ RPKM in the endometrium of cyclic heifers on Day 13 (Additional file 1: Table S1). None of these genes were expressed in the conceptus at levels detectable by RNASEQ $(<0.5$ RPKM). Screening of microarray data indicated increased expression on Day 13 of an additional 10 candidate genes that encode for secreted or extracellular proteins including apolipoprotein A-1 (APOA1), arylsulfatase A (ARSA), cysteine-rich, angiogenic inducer, 61 (CYR61), lecithin-cholesterol acyltransferase ( $L C A T)$, mucin 13, cell surface associated (MUC13), neuromedin $\mathrm{N}(N M N)$, neurochondrin $(N C D N)$, nephronectin (NPNT), neurexophilin 3 (NXPH3) and tubulointerstitial nephritis antigen like-1 (TINAGL1). These were selected as they have not been previously interrogated in the context of conceptus elongation in cattle.

\section{Changes in endometrial gene expression throughout the} estrous cycle and early pregnancy

The endometrial expression of ARSA, MUC13, NXPH3 and PENK increased $(\mathrm{P}<0.05$, day effect) as the estrous cycle/early pregnancy progressed (Figure 1); however, pregnancy status had no significant effect on their expression. No effects of day, pregnancy or their interactions were detected for CYR61 or MGP (Table 3). The expression of APOA1, DCN, LCAT, NCDN, NMN, NPNT, PLIN2 and TINAGL1 was modulated $(\mathrm{P}<0.05$, day effect) as the estrous cycle/early pregnancy progressed (Figure 2). In addition, $A P O A 1, D C N$ and NPNT expression was higher in the endometrium of cyclic compared to pregnant heifers, while pregnancy increased $(\mathrm{P}<0.05)$ the expression of $L C A T$, NCDN, NMN, PLIN2 and TINAGL1 in the endometrium.
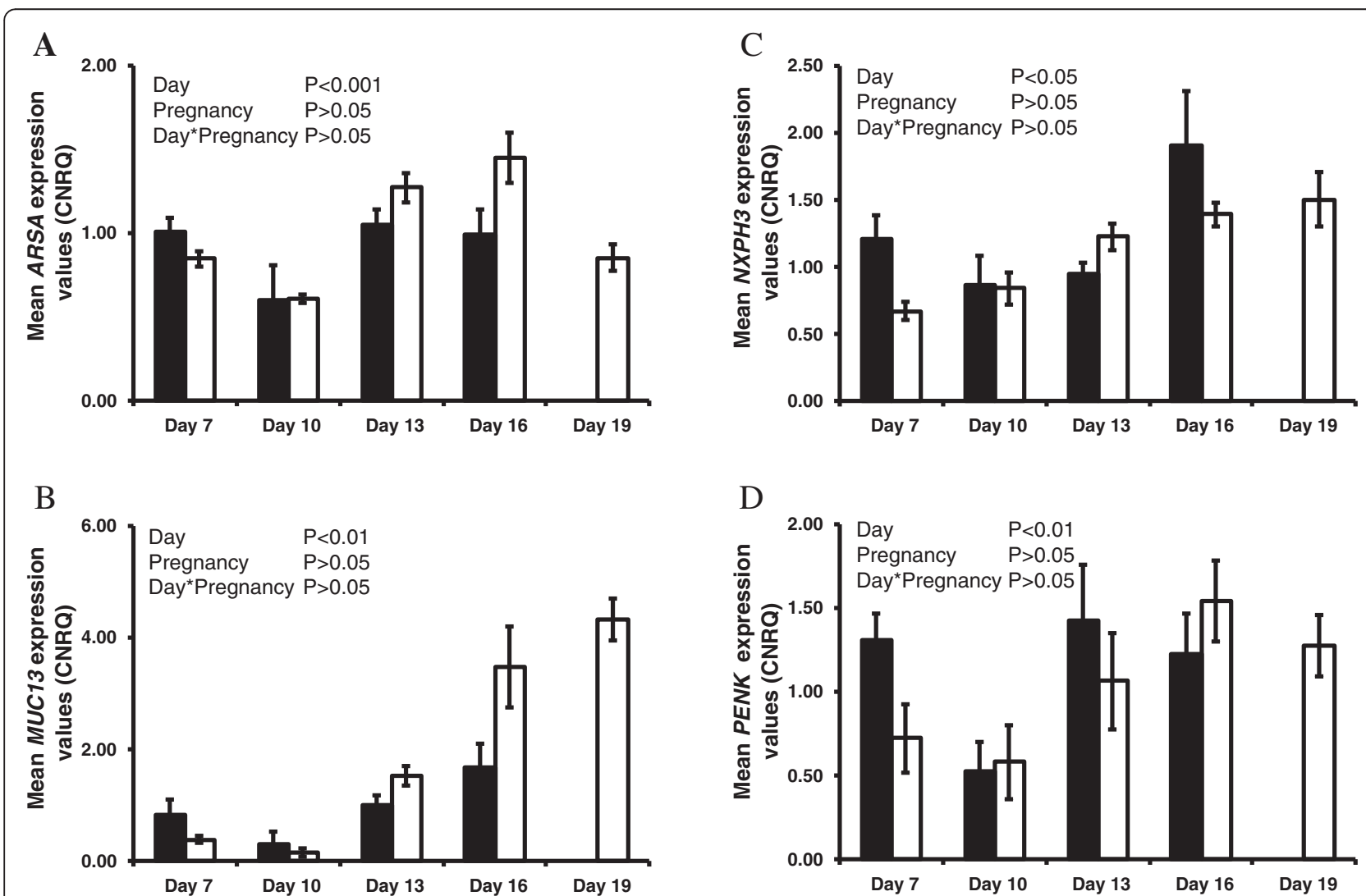

Figure 1 qPCR analysis of candidate genes in the endometrium significantly affected by day of the estrous cycle and early pregnancy. A-D Average calibrated, normalized relative expression values in arbitrary units (CNRQ \pm SEM) determined by qPCR analysis of the endometrium from cyclic (black bars) and pregnant (open bars) heifers ( $n=5$ per treatment per time-point) throughout the estrous cycle and early pregnancy. 
Table 3 A summary of the overall effects of day, pregnancy status and progesterone (P4) concentrations on endometrial expression of selected genes that encode for secreted proteins

\begin{tabular}{|c|c|c|c|c|c|c|}
\hline Gene name & Gene description & Day & Pregnancy & Day *Pregnancy & P4 & $\begin{array}{c}\text { Protein detected } \\
\text { in ULF } \\
\end{array}$ \\
\hline APOA1 & Apolipoprotein A-I & * & * & - & * & YES \\
\hline ARSA & Arylsulfatase A & $* * *$ & - & - & - & YES \\
\hline CYR61 & Cysteine-rich, angiogenic inducer, 61 & - & - & - & - & ND \\
\hline$D C N$ & Decorin Precursor (Bone proteoglycan II)(PG-S2) & $* *$ & * & - & - & ND \\
\hline LCAT & Lecithin-cholesterol acyltransferase & $* *$ & - & * & * & YES \\
\hline MGP & Bos taurus matrix Gla protein (MGP), mRNA. & - & - & - & * & ND \\
\hline MUC13 & Mucin 13 , cell surface associated & ** & - & - & - & ND \\
\hline NCDN & Neurochondrin & ** & * & * & - & YES \\
\hline NMN & Neuromedin N & - & - & * & * & ND \\
\hline NPNT & Nephronectin & $* *$ & * & * & * & ND \\
\hline $\mathrm{NXPH3}$ & Neurexophilin 3 & * & - & - & * & ND \\
\hline PENK & $\begin{array}{l}\text { Proenkephalin A Precursor [Contains Synenkephalin; } \\
\text { Met-enkephalin(Opioid growth factor)(OGF);Met-enkephalin- } \\
\text { Arg-Gly-Leu;Leu-enkephalin;Enkelytin;Met-enkephalin-Arg-Phe] }\end{array}$ & ** & - & - & * & ND \\
\hline PLIN2 & Adipophilin (Adipose differentiation-related protein)(ADRP) & - & * & * & * & YES \\
\hline TINAGL1 & Tubulointerstitial nephritis antigen-like 1 & ** & * & - & * & ND \\
\hline
\end{tabular}

Protein encoded for by these genes were detected in uterine luminal fluid during the period of conceptus elongation (Day 13) through to initiation of implantation (Day 19) by either nano LC MS/MS or iTraq analyses. Significance is set at $\mathrm{P}<0.05(*), \mathrm{P}<0.01(* *)$ or $\mathrm{P}<0.001$ (***). denotes no significant effect of a given treatment. ND = protein product not detected by either method.

\section{Regulation of candidate gene expression in the endometrium by altered progesterone concentrations in vivo}

High and low concentrations of circulating P4 were associated with four main patterns of gene expression in the endometrium. The expression of APOA1, PENK and TINAGL1 was similar among treatment groups on Day 7; however, the magnitude of the normal increase in expression of these genes on Day 13 was reduced $(\mathrm{P}<0.05)$ in heifers with low P4 (Figure 3A, F \& H). In contrast, low $\mathrm{P} 4$ decreased $(\mathrm{P}<0.05)$ the expression of $L C A T$ and NPNT on Day 7 only (Figure 3B \& D), while an early increase $(\mathrm{P}<0.05)$ in the expression of NXPH3 and PLIN2 was observed in heifers with high P4 (Figure 3E \& G). NMN expression was higher $(\mathrm{P}<0.05)$ in low $\mathrm{P} 4$ heifers on Day 7 compared to high and normal P4 groups (Figure 3C), while the expression of $A R S A, D C N$, $M U C 13$ and NCDN was not affected by altered concentrations of circulating P4 (data not shown).

Protein abundance in the ULF during the periimplantation period of early pregnancy

To further test the hypothesis that these molecules play a role in conceptus elongation, the presence of the protein products of these genes in ULF during the periimplantation period of pregnancy was examined. Of the 12 candidate genes which encode for putatively secreted proteins and whose expression was modulated in the endometrium during the estrous cycle and early pregnancy, 5 were detected by either iTraq or nano LC MS/MS analysis of ULF collected on either Days 13, 16 or 19 of pregnancy. Using iTraq, LCAT was detected in ULF of pregnant heifers on Day 13 of pregnancy, while NCDN and PLIN3 were detected on Days 16 and 19. Quantitative changes in their abundance were not detected, however. PLIN1 was detected on Days 13 and 16 of pregnancy by nano LC MS/MS. In contrast APOA1 and ARSA proteins were detected in ULF using both iTraq and nano LC MS/MS on all days of pregnancy examined. The abundance of APOA1 and ARSA declined $(\mathrm{P}<0.05)$ from Day 13 to Day 16 (Figure 4).

\section{Discussion}

In cattle, as in other ruminants, the transition from a blastocyst to a fully elongated conceptus is one of the major morphological events that take place during the peri-implantation period of pregnancy. This process is a maternally-driven event, as elongation does not occur in vivo in the absence of uterine gland secretions in sheep [6], and has yet to be recapitulated in vitro in cattle $[8,9]$. Transfer of in vitro derived blastocysts [18] or trophoblastic vesicles [46] into the uterus of synchronized recipients results in successful conceptus elongation; ULF must therefore contain molecules that drive conceptus elongation. One approach to predicting which proteins are present in ULF is to examine the endometrial expression of selected genes that encode for proteins that are known to be secreted or extracellular in nature. 

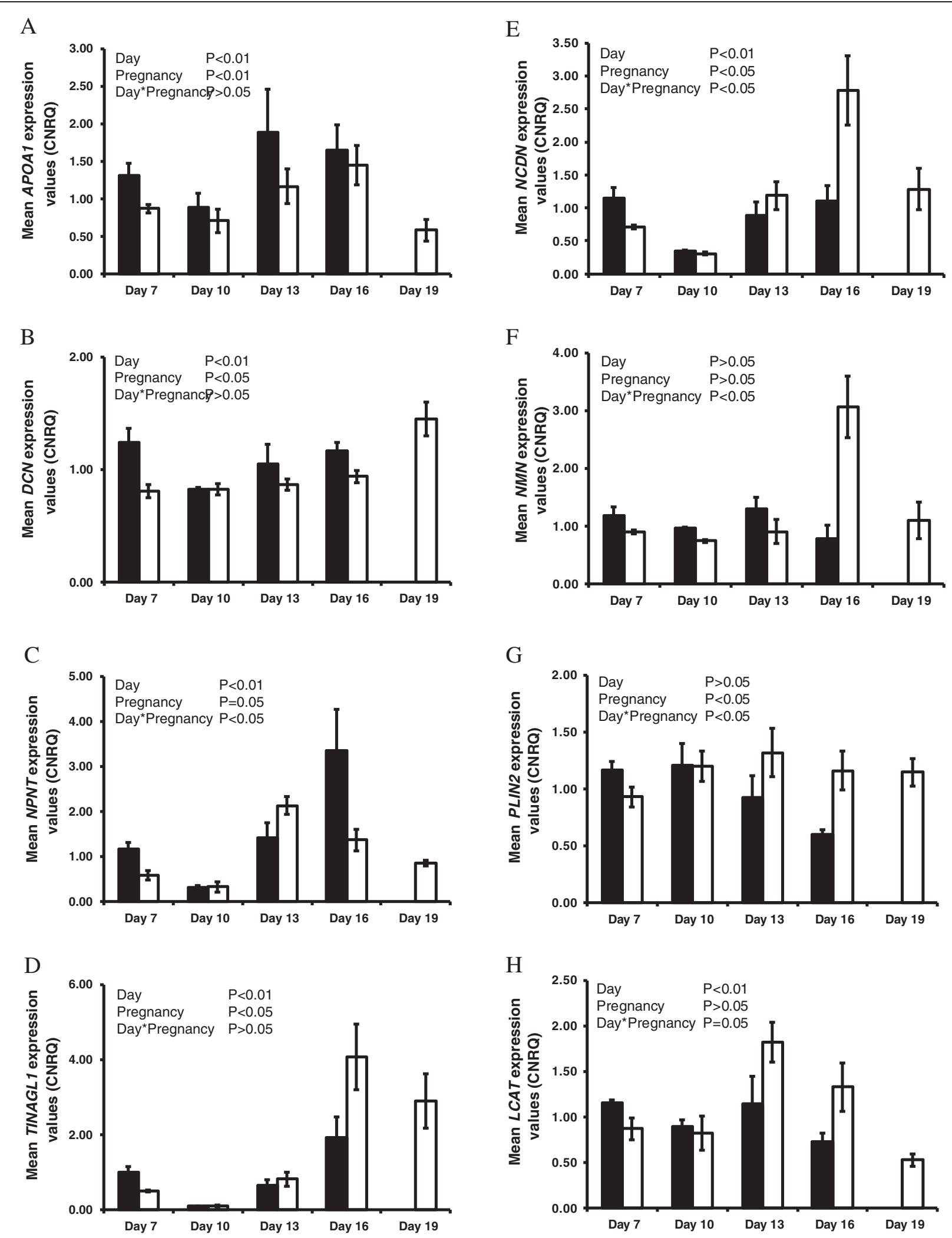

Figure 2 qPCR analysis of candidate genes in the endometrium significantly affected by pregnancy status. A-H Average calibrated, normalized relative expression values in arbitrary units (CNRQ \pm SEM) as determined by qPCR analysis of the endometria from cyclic (black bars) and pregnant (open bars) heifers ( $n=5$ per treatment per time-point) throughout the estrous cycle and early pregnancy. 

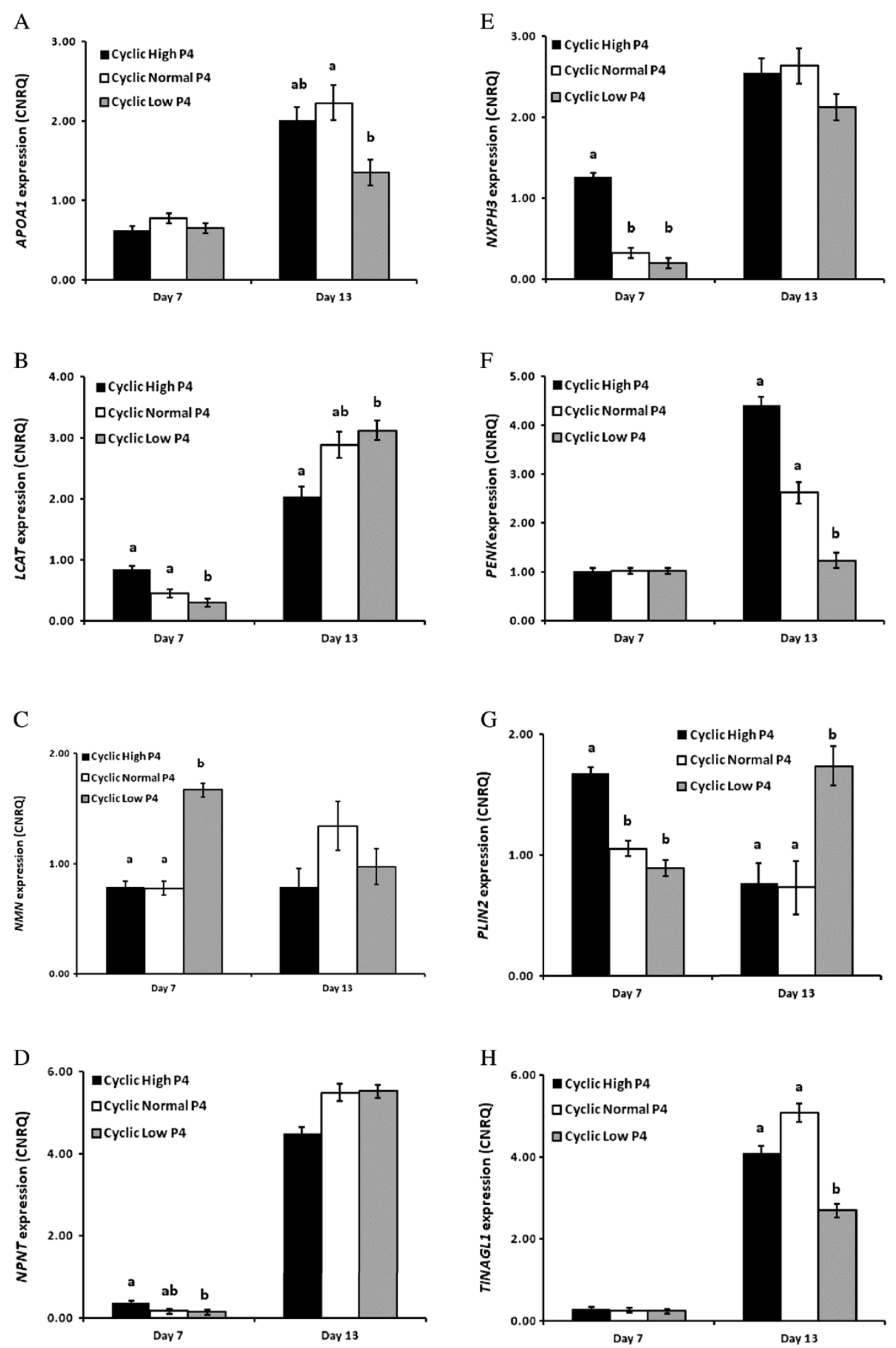

Figure 3 qPCR analysis of candidate genes in the endometrium significantly affected by progesterone. A-H Average calibrated, normalized, relative expression values (CNRQ \pm SEM) as determined by $\mathrm{qPCR}$ in the endometrium of heifers with high (black bars), normal (white bars) and low (gray bars) circulating concentrations of P4 on either Day 7 or Day 13 of the estrous cycle. Significant differences $(P<0.05)$ in gene expression values between treatments on a given day are identified with $a, b$, or $c$. 


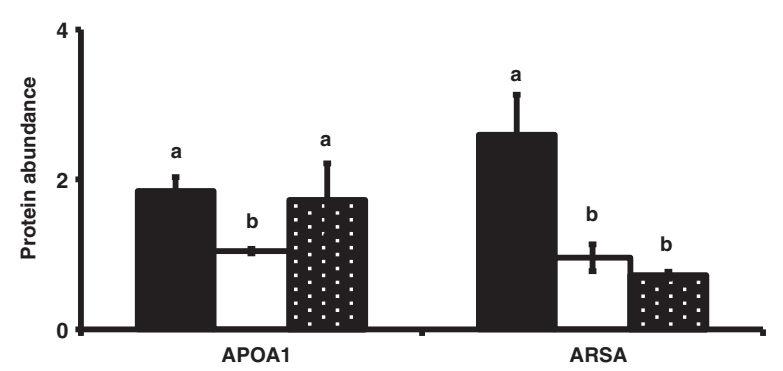

Figure 4 Protein abundance in the uterine luminal fluid for APOA1 and ARSA on Days 13 (solid bars), 16 (open bars) and 19 (black bars, white stipple) of pregnancy based on results from iTraq analysis. Differences $(P<0.05)$ in protein abundance between days are represented with $a, b$, or $c$.

If expression of these genes is modulated during early pregnancy and/or by altered concentrations of $\mathrm{P} 4$ in vivo (which have demonstrable effects on the elongation of the conceptus), it is plausible that they are candidate genes likely to influence conceptus elongation. Using this candidate gene approach, we found that expression of ARSA, MUC13, NXPH3 and PENK increased with advancing stages of the estrous cycle and early pregnancy. Similarly, LCAT, NCDN, NMN, PLIN2 and TINAGL1 expression increased during the later luteal phase, with the presence of the conceptus significantly increasing their expression. In contrast, APOA1, DCN and NPNT expression decreased in pregnant compared with cyclic heifers. A delay in the postovulatory increase in circulating concentrations of $\mathrm{P} 4$ delayed the increase in expression of LCAT and NPNT on Day 7 and APOA1, PENK and TINAGL1 on Day 13, the day on which conceptus elongation is initiated. Finally, comparison of this list of candidate genes with the protein content of ULF of pregnant heifers during conceptus elongation (Days 13 through 19) indicated the presence of APOA1, ARSA, LCAT, NCDN as well as members of the PLIN family, lending validity to this candidate gene expression approach.

In cattle, two of the main molecules that affect endometrial gene expression are circulating concentrations of P4 and conceptus-derived IFNT, both of which can affect the composition of the ULF and alter the rate of conceptus elongation. The comparison of gene expression in the endometrium and proteins present in ULF identified four proteins (APOA1, ARSA, LCAT and NCDN) from 14 candidate genes, while two members of the perilipin family were detected. At first glance, the number of proteins detected in ULF in comparison to the number of candidate genes may seem low. However, it is important to note that there is at least an order of magnitude in the difference between the number of total transcripts detectable in the endometrium by RNA-SEQ ( 21,000 transcripts: [41]) versus the number of total proteins detected in ULF by proteomics [47]. In addition, analysis of gene expression was performed on endometrial homogenates which contain a heterogenous cell population. It is possible that, despite their status as genes that encode for extracellular/secreted proteins, their expression may be predominantly stromal in nature, similar to the expression of HGF [48] and FGF10 [49] in the sheep endometrium. As such, the protein products of these genes may not be secreted into ULF, but may act in a more autocrine or paracrine manner within the endometrium.

The patterns of expression of ARSA, MUC13, NXPH3 and PENK were similar in endometria from both pregnant and cyclic heifers. MUC13 exhibited minimal expression on Day 7 and 10, while ARSA, NXPH3 and PENK expression decreased on Day 10, but increased significantly during the late luteal phase of the estrous cycle and as pregnancy progressed. Given that the expression of these genes increased during the luteal phase of the estrous cycle and early pregnancy, we propose that they play a role in establishing uterine receptivity to implantation. Although the protein products of NXPH3 or PENK were not detected in ULF, the increased mRNA abundance for these genes in endometria of P4-supplemented heifers strongly suggests that they contribute to advancing conceptus elongation after both artificial insemination [11] and embryo transfer [18].

In contrast, endometrial expression of $A P O A 1, D C N$ and NPNT decreased in to the presence of the developing conceptus. Expression of both APOA1 and NPNT was modulated by P4, with a delay on Day 13 in $A P O A 1$ expression, while $\mathrm{P} 4$ supplementation resulted in an early increase in NPNT on Day 7. We propose that the decreased expression of these genes in endometria in the periimplantation period of pregnancy, may be a pre-requisite for establishing uterine receptivity to implantation, similar to that observed for nuclear $\mathrm{P} 4$ receptors in all species studied [50] as well as MUC1 in sheep [51].

The modulation of circulating concentrations of $\mathrm{P} 4$ in cattle and sheep has demonstrable effects on gene expression in the endometrium and timing of conceptus elongation. In cattle, this results in altered trajectories of conceptus elongation on Day 14 following embryo transfer on Day 7. Exogenous supplementation of P4 advances conceptus elongation [18]; conversely, when P4 output from the CL is diminished [40], conceptus elongation is delayed. High circulating concentrations of $\mathrm{P} 4$ advanced the normal increase of $N X P H 3$ expression on Day 7 of the estrous cycle, while in heifers with low P4 the normal expression level of NPNT was decreased. In addition, decreased expression of $A P O A 1$ and PENK on Day 13 in heifers with low P4 and delayed conceptus elongation suggests that these endometrial genes and their protein products contribute to the process of 
conceptus elongation. This hypothesis is supported by evidence for the presence of APOA1 protein in ULF on both Day 13 and 16.

Of the 14 candidate genes examined, changes in expression of NMN, PLIN2 and TINAGL1 were of particular interest. Neurotensin (NT) was first isolated from the bovine hypothalamus [52] and small intestine [53] and NMN protein, along with NT is derived from the same precursor peptide with the resulting active form of the peptides (i.e., NT or NMN) being dependent of the site of cleavage of the pro-peptide (reviewed by [54]). Interestingly, the predominant forms of the processed peptides are tissue-specific, e.g., the long form of NMN is the predominant form in the gut [55]. NMN expression was similar in pregnant and cyclic heifers up to Day 16 when pregnancy recognition occurs and was modulated by low circulating concentrations of P4. NMN protein was not detected in ULF, but a protein that degrades NMN, aminopeptidase $M$ [56], has been detected in ULF [47]. This may explain in part why NMN protein was not detected and, given its expression pattern, may suggest that NMN is involved in the pregnancy recognition response in the endometrium rather than conceptus elongation itself.

TINAGL1 is a matri-cellular protein that can interact with both extracellular matrix proteins and cell surface receptors. In mice, TINAGL1 is expressed by the trophectoderm and interacts with laminin 1 [57]. TINAGL1 expression increases in the endometrium of pregnant mice as well as at the sites of implantation where the abundance of protein increases during the later stages of implantation [58]. In addition, TINAGL1 has been linked to the integrins ITGA5 and ITGB1 in the decidua [58]. In the current study, TINAGL1 expression was minimal from Day 7 to 13, but increased on Day 16 and to a greater extent in pregnant than cyclic heifers. This is interesting as there is basal expression when the uterus is not receptive to implantation (i.e., when PGR is expressed by uterine LE and GE). TINAGL1 expression increases after uterine receptivity to implantation is established, but interestingly, its expression on Day 13, when conceptus elongation is initiated, is minimal. Moreover, TINAGL1 protein is not detectable in ULF. Thus, TINALG1 in the endometrium of cattle is not directly involved in conceptus elongation, but instead plays a role in implantation as evidenced by its increase in expression in pregnant heifers on Days 16 and 19, similar to its role in mice.

PLIN2 (a.k.a. ADRP) protein is involved in lipid droplet formation and, in particular, the intracellular storage of triaclyglycerols (TAG: reviewed by [59]). It is also detectable in milk lipid droplets secreted from mammary epithelial cells in a variety of species including humans, rats and cattle [60]. Triaclyglycerols have been detected in the ULF of cattle [61] and in vitro TAG is utilized as an energy source by the embryo up to the blastocyst stage of development [62]. In both breast cancer and leiomyoma human cell lines, the PLIN2 gene has a PGR response element in its promoter region. Given its modulation by $\mathrm{P} 4$ in vivo and its increased expression in pregnant heifers likely due to IFNT [63], as well as detection of PLIN2 family members in ULF of cattle, it is likely that PLIN2 contributes to the secretion and /or transport of TAG into the ULF as an energy source for the developing conceptus during elongation.

\section{Conclusion}

Using a candidate gene approach, we determined that the expression of PENK is affected by altered concentrations of $\mathrm{P} 4$ in blood while pregnancy increases and decreases the expression of $N C D N$ and $D C N$, respectively. In addition, we determined that both $\mathrm{P} 4$ manipulation and the presence of the conceptus alter endometrial expression of PLIN2, TINAGL1, NPNT, LCAT, NMN and $A P O A 1$. Comparison of the expression profiles of these genes to proteins detected in ULF during conceptus elongation (i.e., Days 13 through 19) revealed the presence of APOA1, ARSA, LCAT, NCDN as well as members of the PLIN family of proteins that may play roles in driving conceptus elongation in cattle.

\section{Additional file}

Additional file 1: Table S1. Average expression values in transcripts per million (TPM \pm SEM) for genes with a cellular component of extracellular space in the endometrium of cyclic heifers on Day 13 of the estrous cycle. No detecteble expression values for these genes was observed in the ovoid conceputs at the same stage following estrus (Day 13).

\section{Competing interests}

The authors declare that they have no competing interests.

\section{Authors' contributions}

NF and PL performed the sample collection. NF performed the laboratory analysis of the endometrium/uterine samples. SM performed gene expression analysis on the embryo. JPM, PMcG and NF performed data analysis. NF, FWB, TES and PL were involved in the conception and design of the study. NF drafted the manuscript. FWB, TES and PL critically revised the manuscript. All authors read, commented and approved the final version of the manuscript.

\section{Acknowledgements}

We wish to acknowledge the help of staff and students who assisted in sample collection. This work was supported by Science Foundation Ireland under grant number 10/IN.1/B3011 (the opinions, findings and conclusions or recommendations expressed in this material are those of the authors and do not necessarily reflect the views of the Science Foundation Ireland).

\section{Author details}

'School of Agriculture and Food Science, University College Dublin, Dublin, Ireland. ${ }^{2}$ Conway Institute of Biomolecular and Biomedical Science, University College Dublin, Dublin, Ireland. ${ }^{3}$ Department of Animal Science, Texas A\&M University, College Station, Texas 77843-2471, USA. ${ }^{4}$ Center for Reproductive Biology, Department of Animal Sciences, Washington State University, Pullman, Washington 99164-6353, USA. ${ }^{5}$ Veterinary Sciences Centre, School 
of Agriculture and Food Science, University College Dublin, Belfield, Dublin 4, Ireland.

Received: 23 November 2012 Accepted: 3 May 2013

Published: 10 May 2013

\section{References}

1. Diskin MG, Morris DG: Embryonic and early foetal losses in cattle and other ruminants. Reproduction in domestic animals = Zuchthygiene 2008, 43(Suppl 2):260-267.

2. Diskin MG, Murphy JJ, Sreenan JM: Embryo survival in dairy cows managed under pastoral conditions. Anim Reprod Sci 2006, 96(3-4):297-311.

3. Northey DL, French LR: Effect of embryo removal and intrauterine infusion of embryonic homogenates on the lifespan of the bovine corpus luteum. J Anim Sci 1980, 50(2):298-302.

4. Betteridge KJ, Eaglesome MD, Randall GC, Mitchell D: Collection, description and transfer of embryos from cattle 10-16 days after oestrus. J Reprod Fertil 1980, 59(1):205-216.

5. Bazer FW: Uterine protein secretions: Relationship to development of the conceptus. J Anim Sci 1975, 41(5):1376-1382.

6. Gray CA, Burghardt RC, Johnson GA, Bazer FW, Spencer TE: Evidence that absence of endometrial gland secretions in uterine gland knockout ewes compromises conceptus survival and elongation. Reproduction (Cambridge, England) 2002, 124(2):289-300.

7. Spencer TE, Gray CA: Sheep uterine gland knockout (UGKO) model. Methods Mol Med 2006, 121:85-94.

8. Alexopoulos NI, Vajta G, Maddox-Hyttel P, French AJ, Trounson AO: Stereomicroscopic and histological examination of bovine embryos following extended in vitro culture. Reprod Fertil Dev 2005, 17(8):799-808.

9. Brandao DO, Maddox-Hyttel P, Lovendahl P, Rumpf R, Stringfellow D, Callesen $\mathrm{H}$ : Post hatching development: a novel system for extended in vitro culture of bovine embryos. Biol Reprod 2004, 71(6):2048-2055.

10. Garrett JE, Geisert RD, Zavy MT, Morgan GL: Evidence for maternal regulation of early conceptus growth and development in beef cattle. J Reprod Fertil 1988, 84(2):437-446.

11. Carter F, Forde N, Duffy P, Wade M, Fair T, Crowe MA, Evans AC, Kenny DA Roche JF, Lonergan P: Effect of increasing progesterone concentration from Day 3 of pregnancy on subsequent embryo survival and development in beef heifers. Reprod Fertil Dev 2008, 20(3):368-375.

12. Satterfield MC, Song G, Kochan KJ, Riggs PK, Simmons RM, Elsik CG, Adelson DL, Bazer FW, Zhou H, Spencer TE: Discovery of candidate genes and pathways in the endometrium regulating ovine blastocyst growth and conceptus elongation. Physiol Genomics 2009, 39(2):85-99.

13. Mann GE, Lamming GE: Relationship between maternal endocrine environment, early embryo development and inhibition of the luteolytic mechanism in cows. Reproduction (Cambridge, England) 2001, 121(1):175-180.

14. Mann GE, Fray MD, Lamming GE: Effects of time of progesterone supplementation on embryo development and interferon-tau production in the cow. Vet J 2006, 171(3):500-503.

15. Stronge AJ, Sreenan JM, Diskin MG, Mee JF, Kenny DA, Morris DG: Postinsemination milk progesterone concentration and embryo survival in dairy cows. Theriogenology 2005, 64(5):1212-1224.

16. McNeill RE, Diskin MG, Sreenan JM, Morris DG: Associations between milk progesterone concentration on different days and with embryo survival during the early luteal phase in dairy cows. Theriogenology 2006, 65(7):1435-1441.

17. Ashworth CJ, Sales DI, Wilmut I: Evidence of an association between the survival of embryos and the periovulatory plasma progesterone concentration in the ewe. J Reprod Fertil 1989, 87(1):23-32.

18. Clemente M, De La Fuente J, Fair T, Al Naib A, Gutierrez-Adan A, Roche JF, Rizos D, Lonergan P: Progesterone and conceptus elongation in cattle: a direct effect on the embryo or an indirect effect via the endometrium? Reproduction (Cambridge, England) 2009, 138(3):507-517.

19. Forde NL, P: Transcriptomic Analysis of the Bovine Endometrium: What is Required to Establish Uterine Receptivity to Implantation in Cattle? J Reprod Dev 2012, 58(2):189-195

20. Bazer FW, Wu G, Spencer TE, Johnson GA, Burghardt RC, Bayless K: Nove pathways for implantation and establishment and maintenance of pregnancy in mammals. Mol Hum Reprod 2010, 16(3):135-152.

21. Bazer FWK, Hakhyun J, Johnson KA, Wu GA, Song G: Select Nutrients in the Uterine Lumen of Sheep and Pigs Affect Conceptus Development. J Reprod Dev 2012, 58(2):180-188.
22. Spencer TE, Bartol FF, Bazer FW, Johnson GA, Joyce MM: Identification and characterization of glycosylation-dependent cell adhesion molecule 1-like protein expression in the ovine uterus. Biol Reprod 1999, 60(2):241-250.

23. Song G, Spencer TE, Bazer FW: Cathepsins in the ovine uterus: regulation by pregnancy, progesterone, and interferon tau. Endocrinology 2005, 146(11):4825-4833.

24. Song G, Bazer FW, Wagner GF, Spencer TE: Stanniocalcin (STC) in the endometrial glands of the ovine uterus: regulation by progesterone and placental hormones. Biol Reprod 2006, 74(5):913-922

25. Song G, Spencer TE, Bazer FW: Progesterone and interferon-tau regulate cystatin C in the endometrium. Endocrinology 2006, 147(7):3478-3483.

26. Song G, Satterfield MC, Kim J, Bazer FW, Spencer TE: Gastrin-releasing peptide (GRP) in the ovine uterus: regulation by interferon tau and progesterone. Biol Reprod 2008, 79(2):376-386.

27. Simmons RM, Erikson DW, Kim J, Burghardt RC, Bazer FW, Johnson GA Spencer TE: Insulin-like Growth Factor Binding Protein One in the Ruminant Uterus: Potential Endometrial Marker and Regulator of Conceptus Elongation. Endocrinology 2009, 150(9):4295-4305

28. Dorniak P, Bazer FW, Spencer TE: Prostaglandins regulate conceptus elongation and mediate effects of interferon tau on the ovine uterine endometrium. Biol Reprod 2011, 84(6):1119-1127.

29. Dorniak P, Welsh TH Jr, Bazer FW, Spencer TE: Endometrial HSD11B1 and cortisol regeneration in the ovine uterus: effects of pregnancy, interferon tau, and prostaglandins. Biol Reprod 2011, 86(4):124.

30. Gao H, Wu G, Spencer TE, Johnson GA, Bazer FW: Select nutrients in the ovine uterine lumen. III. Cationic amino acid transporters in the ovine uterus and peri-implantation conceptuses. Biol Reprod 2009, 80(3):602-609.

31. Gao H, Wu G, Spencer TE, Johnson GA, Bazer FW: Select nutrients in the ovine uterine lumen. IV. Expression of neutral and acidic amino acid transporters in ovine uteri and peri-implantation conceptuses. Biol Reprod 2009, 80(6):1196-1208

32. Gao H, Wu G, Spencer TE, Johnson GA, Bazer FW: Select nutrients in the ovine uterine lumen. II. Glucose transporters in the uterus and periimplantation conceptuses. Biol Reprod 2009, 80(1):94-104.

33. Costello LM, O'Boyle P, Godkin JD, Diskin MG, Hynes AC, Morris DG: Retinol-binding protein (RBP), retinol and beta-carotene in the bovine uterus and plasma during the oestrous cycle and the relationship between systemic progesterone and RBP on day 7. Reprod Fertil Dev 2010, 22(8):1198-1205.

34. Mullen MP, Forde N, Parr MH, Diskin MG, Morris DG, Nally JE, Evans AC, Crowe MA: Alterations in systemic concentrations of progesterone during the early luteal phase affect RBP4 expression in the bovine uterus. Reprod Fertil Dev 2012, 24(5):715-722.

35. Ledgard AM, Lee RS, Peterson AJ: Bovine endometrial legumain and TIMP2 regulation in response to presence of a conceptus. Mol Reprod Dev 2009, 76(1):65-74.

36. Dorniak P, Bazer FW, Spencer TE: Biological role of interferon tau in endometrial function and conceptus elongation. J Anim Sci 2012, 91(4):1627-1638.

37. Gray CA, Adelson DL, Bazer FW, Burghardt RC, Meeusen EN, Spencer TE: Discovery and characterization of an epithelial-specific galectin in the endometrium that forms crystals in the trophectoderm. Proc Natl Acad Sci USA 2004, 101(21):7982-7987.

38. Lewis SK, Farmer JL, Burghardt RC, Newton GR, Johnson GA, Adelson DL, Bazer FW, Spencer TE: Galectin 15 (LGALS15): a gene uniquely expressed in the uteri of sheep and goats that functions in trophoblast attachment. Biol Reprod 2007, 77(6):1027-1036.

39. Forde N, Carter F, Fair T, Crowe MA, Evans AC, Spencer TE, Bazer FW, McBride R, Boland MP, O'Gaora P, et al: Progesterone-regulated changes in endometrial gene expression contribute to advanced conceptus development in cattle. Biol Reprod 2009, 81(4):784-794.

40. Forde N, Beltman ME, Duffy GB, Duffy P, Mehta JP, O'Gaora P, Roche JF, Lonergan $\mathrm{P}$, Crowe MA: Changes in the endometrial transcriptome during the bovine estrous cycle: effect of low circulating progesterone and consequences for conceptus elongation. Biol Reprod 2011, 84(2):266-278.

41. Forde N, Duffy GB, McGettigan PA, Browne JA, Mehta JP, Kelly AK, MansouriAttia N, Sandra O, Loftus BJ, Crowe MA, et al: Evidence for an early endometrial response to pregnancy in cattle: both dependent upon and independent of interferon tau. Physiol Genomics 2012, 44(16):799-810.

42. Forde N, Mehta JP, Minten M, Crowe MA, Roche JF, Spencer TE, Lonergan P: Effects of Low Progesterone on the Endometrial Transcriptome in Cattle. Biol Reprod 2012, 87(5):124. 
43. Mamo S, Mehta JP, McGettigan P, Fair T, Spencer TE, Bazer FW, Lonergan P: RNA sequencing reveals novel gene clusters in bovine conceptuses associated with maternal recognition of pregnancy and implantation. Biol Reprod 2011, 85(6):1143-1151.

44. Mamo S, Mehta JP, Forde N, McGettigan P, Lonergan P: Conceptusendometrium crosstalk during maternal recognition of pregnancy in cattle. Biol Reprod 2012, 87(1):6. 1-9.

45. Beltman ME, Roche JF, Lonergan P, Forde N, Crowe MA: Evaluation of models to induce low progesterone during the early luteal phase in cattle. Theriogenology 2009, 72(7):986-992.

46. Flechon JE, Guillomot M, Charlier M, Flechon B, Martal J: Experimental studies on the elongation of the ewe blastocyst. Reprod Nutr Dev 1986, 26(4):1017-1024

47. Mullen MP, Elia G, Hilliard M, Parr MH, Diskin MG, Evans AC, Crowe MA: Proteomic characterization of histotroph during the preimplantation phase of the estrous cycle in cattle. J Proteome Res 2012, 11(5):3004-3018.

48. Chen C, Spencer TE, Bazer FW: Expression of hepatocyte growth factor and its receptor c-met in the ovine uterus. Biol Reprod 2000, 62(6):1844-1850.

49. Chen C, Spencer TE, Bazer FW: Fibroblast growth factor-10: a stromal mediator of epithelial function in the ovine uterus. Biol Reprod 2000, 63(3):959-966.

50. Bazer FW, Spencer TE, Johnson GA, Burghardt RC, Wu G: Comparative aspects of implantation. Reproduction (Cambridge, England) 2009, 138(2):195-209.

51. Johnson GA, Bazer FW, Jaeger LA, Ka H, Garlow JE, Pfarrer C, Spencer TE, Burghardt RC: Muc-1, integrin, and osteopontin expression during the implantation cascade in sheep. Biol Reprod 2001, 65(3):820-828.

52. Carraway R, Leeman SE: The isolation of a new hypotensive peptide, neurotensin, from bovine hypothalami. J Biol Chem 1973, 248(19):6854-6861.

53. Kitabgi P, Carraway R, Leeman SE: Isolation of a tridecapeptide from bovine intestinal tissue and its partial characterization as neurotensin. J Biol Chem 1976, 251(22):7053-7058.

54. Kitabgi P: Differential processing of pro-neurotensin/neuromedin $\mathrm{N}$ and relationship to pro-hormone convertases. Peptides 2006, 27(10):2508-2514.

55. Carraway RE, Mitra SP: Differential processing of neurotensin/ neuromedin $\mathrm{N}$ precursor(s) in canine brain and intestine. J Biol Chem 1990, 265(15):8627-8631.

56. Dubuc I, Nouel D, Coquerel A, Menard JF, Kitabgi P, Costentin J: Hypothermic effect of neuromedin $\mathrm{N}$ in mice and its potentiation by peptidase inhibitors. Eur J Pharmacol 1988, 151(1):117-121.

57. Igarashi T, Tajiri Y, Sakurai M, Sato E, Li D, Mukai K, Suematsu M, Fukui E, Yoshizawa $M$, Matsumoto H: Tubulointerstitial nephritis antigen-like 1 is expressed in extraembryonic tissues and interacts with laminin 1 in the Reichert membrane at postimplantation in the mouse. Biol Reprod 2009, 81(5):948-955.

58. Tajiri Y, Igarashi T, Li D, Mukai K, Suematsu M, Fukui E, Yoshizawa M, Matsumoto $\mathrm{H}$ : Tubulointerstitial nephritis antigen-like 1 is expressed in the uterus and binds with integrins in decidualized endometrium during postimplantation in mice. Biol Reprod 2010, 82(2):263-270

59. Ducharme NA, Bickel PE: Lipid droplets in lipogenesis and lipolysis. Endocrinology 2008, 149(3):942-949.

60. Heid HW, Schnolzer M, Keenan TW: Adipocyte differentiation-related protein is secreted into milk as a constituent of milk lipid globule membrane. Biochem J 1996, 320(Pt 3):1025-1030.

61. Meier S, Walker CG, Mitchell MD, Littlejohn MD, Roche JR: Modification of endometrial fatty acid concentrations by the pre-implantation conceptus in pasture-fed dairy cows. J Dairy Res 2011, 78(3):263-269.

62. Ferguson $\mathrm{EM}$, Leese $\mathrm{HJ}$ : A potential role for triglyceride as an energy source during bovine oocyte maturation and early embryo development. Mol Reprod Dev 2006, 73(9):1195-1201

63. Bauersachs S, Ulbrich SE, Reichenbach HD, Reichenbach M, Buttner M, Meyer HH, Spencer TE, Minten M, Sax G, Winter G, et al: Comparison of the effects of early pregnancy with human interferon, alpha 2 (IFNA2), on gene expression in bovine endometrium. Biol Reprod 2012, 86(2):46.

doi:10.1186/1471-2164-14-321

Cite this article as: Forde et al: Alterations in expression of endometrial genes coding for proteins secreted into the uterine lumen during conceptus elongation in cattle. BMC Genomics 2013 14:321.

\section{Submit your next manuscript to BioMed Central and take full advantage of:}

- Convenient online submission

- Thorough peer review

- No space constraints or color figure charges

- Immediate publication on acceptance

- Inclusion in PubMed, CAS, Scopus and Google Scholar

- Research which is freely available for redistribution 